Hartridge, H. \& Roughton, F. J. W. (1923). Proc. Roy. Soc. A, 104, 395.

Jellinek, K. (1912). Samml. chem. Vortr. 18, 1.

Keilin, D. (1926). Proc. Roy. Soc. B, 100, 129.

Keilin, D. (1927). C.R. Soc. Biol., Paris, 97, (Réunion pléniere, Mai), p. 39.

Legge, J. W. \& Roughton, F.J. W.(1950). Biochem.J.47,43.

Lemberg, R. \& Legge, J. W. (1949). Haematin Compounds and Bile Pigments, 1st ed. New York : Interscience.
Lemberg, R., Legge, J. W: \& Lockwood, W. H. (1941). Biochem. J. 35, 339.

Millikan, G. A. (1933). J. Physiol. 79, 158.

Millikan, G. A. (1936). Proc. Roy. Soc. B, 120, 366.

Roughton, F. J. W. (1949). Haemoglobin, p. 83. London: Butterworths Scientific Publications.

Vogel, A. I. (1939). Quantitative Inorganic Analysis, 1st ed., p. 810. London: Longmans Green and Co.

Zeile, K. (1932). Hoppe-Seyl. Z. 207, 35.

\title{
Spectrokinetic Studies of the Reaction of Hydrogen Peroxide with Haemoglobin in Dithionite Solutions
}

\author{
BY K. DALZIEL AND J. R. P. O'BRIEN \\ Department of Biochemistry (Radcliffe Infirmary), University of Oxford
}

(Received 27 February 1957)

It was shown (Dalziel \& O'Brien, 1957) that the action of oxygen on haemoglobin in dithionite solution converts part of the haemoglobin into an unstable derivative which, with excess of dithionite, largely reverts to haemoglobin. Small amounts of stable, choleglobin-like products were formed. These reactions were attributed to the action of hydrogen peroxide formed in the autoxidation of dithionite (cf. Lemberg, Legge \& Lockwood, $1941 b$; Legge \& Roughton, 1950).

In this paper studies of the reaction of hydrogen peroxide with haemoglobin in an excess of dithionite are described.

\section{EXPERIMENTAL}

Buffered solutions of $\mathrm{H}_{2} \mathrm{O}_{2}$ and of haemoglobin (Hb) containing $\mathrm{Na}_{2} \mathrm{~S}_{2} \mathrm{O}_{4}$ were studied in the rapid-reaction apparatus (Dalziel, 1953, 1954; Dalziel \& O'Brien, 1954a). The solutions were mixed in the absence of air and the extinction was recorded 0.2 or $0.8 \mathrm{sec}$. after mixing. Stopped-flow measurements were also made. The extinction at zero time was obtained by flowing the $\mathrm{Hb}$-dithionite reactant with a dithionite solution instead of $\mathrm{H}_{2} \mathrm{O}_{2}$. Spectrokinetic curves were drawn from such measurements at different wavelengths.

Samples of the reaction mixture, and control samples of the $\mathrm{Hb}$ reactant mixed with $\mathrm{Na}_{2} \mathrm{~S}_{2} \mathrm{O}_{4}$ solution instead of $\mathrm{H}_{2} \mathrm{O}_{2}$, were collected from the apparatus, covered with a layer of liquid paraffin and their absorption spectra subsequently measured.

\section{Reagents and derivatives}

Hydrogen peroxide. A.R. ' 20 vol.' reagent was diluted in buffer solution as required. The stock reagent was repeatedly analysed by titration with $\mathrm{KMnO}_{4}$.

Haemoglobin. Except where otherwise stated, the experiments were made with $\mathrm{Hb}$ solutions free from catalase, prepared from haemolysates of washed human red cells by treatment with alumina. The $\mathrm{Hb}$ concentration was estimated spectrophotometrically after conversion into cyan- methaemoglobin (Drabkin \& Austin, 1935-36; Dalziel \& O'Brien, 1954a). Solid $\mathrm{Na}_{2} \mathrm{~S}_{2} \mathrm{O}_{4}$ (a fresh dry commercial sample stored in a sealed bottle) was put in the reactant vessel of the apparatus, and oxyhaemoglobin $\left(\mathrm{HbO}_{2}\right)$ solution poured in and immediately covered with paraffin.

Metmyoglobin (MetMb). Crystalline horse metmyoglobin (Theorell \& Ehrenberg, 1951) was dissolved in water, dialysed free from $\left(\mathrm{NH}_{4}\right)_{2} \mathrm{SO}_{4}$, and finally dialysed against borate buffer ( $\mathrm{pH} \mathrm{8.5)}$. The concentration of MetMb in the stock solution was determined spectrophotometrically after conversion into cyan-metmyoglobin (Drabkin, 1945).

Buffer solutions. These were Clarke and Lubs buffer $0.05 \mathrm{M}$ $\mathrm{KH}_{2} \mathrm{PO}_{4}-\mathrm{NaOH}\left(\mathrm{pH} \mathrm{6.0-8.0)}\right.$ and $0.05 \mathrm{M}-\mathrm{H}_{3} \mathrm{BO}_{3}-\mathrm{KCl}-$ $\mathrm{NaOH}$ (pH 8.0-9.5) (Vogel, 1939).

Denatured globin carboxyhaemochromogens. These were prepared by the method of Lemberg et al. (1941b) and will be referred to as CO-haemochromogens.

Reactant concentrations. Initial concentration in the reaction mixture is referred to throughout. $\mathrm{Hb}$ concentrations are expressed in $\mathrm{m}$-equiv./l.; $\mathrm{mEq}$.- $\mathrm{Hb}$ is equivalent to mM-haem, and $m$-equiv. extinction coefficients, $\epsilon_{\mathrm{mEq}}$, refer to these concentration units; the range of $\mathrm{Hb}$ concentrations used was $0.02-0.50 \mathrm{~m}$-equiv./l. The concentration of $\mathrm{Na}_{2} \mathrm{~S}_{2} \mathrm{O}_{4}$ was varied from 0.05 to $2 \cdot 0 \%(w / v)$. The $\mathrm{H}_{2} \mathrm{O}_{2}$ concentrations were in the range $0 \cdot 5-20 \mathrm{~m}$-moles $/ \mathrm{l}$.

\section{RESULTS}

\section{Products of the overall reaction}

The reaction between $\mathrm{Hb}$ in $\mathrm{Na}_{2} \mathrm{~S}_{2} \mathrm{O}_{4}$ solution and $\mathrm{H}_{2} \mathrm{O}_{2}$ was studied spectrophotometrically at $\mathrm{pH} \mathrm{5 \cdot 9}$, $7 \cdot 0,7 \cdot 7,8 \cdot 0,8 \cdot 4,9 \cdot 0$ and $9 \cdot 5$. A comparison of the absorption spectra at $\mathrm{pH} 5.9$ and 7.7 with that of $\mathrm{Hb}$ in $\mathrm{Na}_{2} \mathrm{~S}_{2} \mathrm{O}_{4}$ solution illustrates the main features of the overall reaction (Fig. $1 A$ ). Depending upon the $\mathrm{pH}$, there is a variable loss of $\mathrm{Hb}$ and the formation of substances absorbing in the orange part of the spectrum; these changes are confirmed by the spectra of the reaction products after addition of alkali and $\mathrm{CO}$ (Fig. $1 B$ ). 


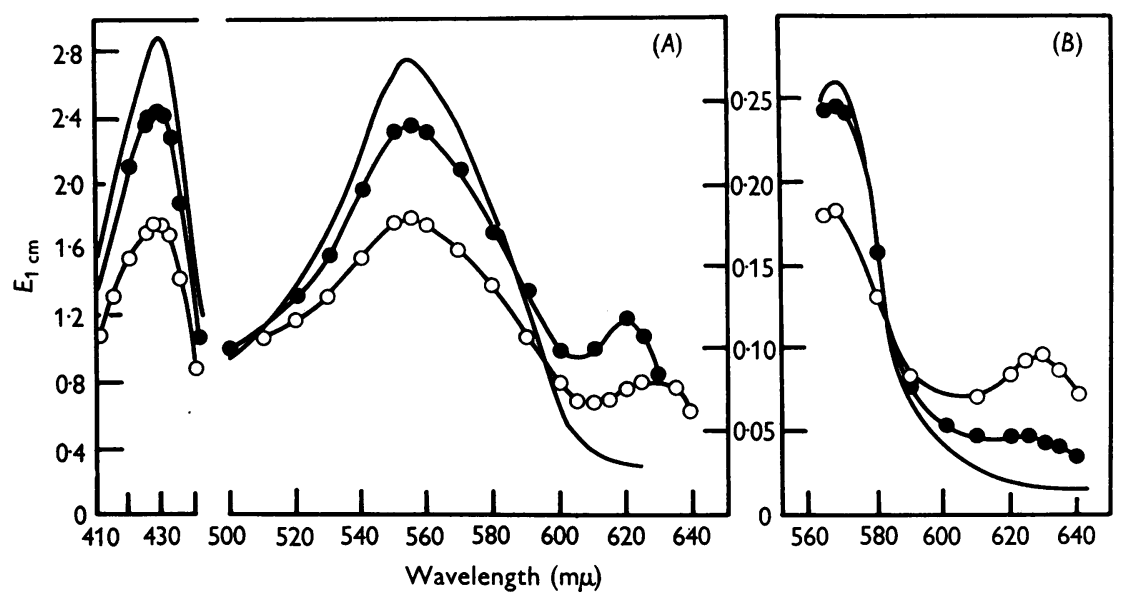

Fig. 1. (A) Absorption spectra of the products of the reaction of $0.02 \mathrm{mEq} \cdot-\mathrm{Hb}, 0 \cdot 1 \% \mathrm{Na}_{2} \mathrm{~S}_{2} \mathrm{O}_{4}$ and $2 \mathrm{~mm}-\mathrm{H}_{2} \mathrm{O}_{2}$ at pH 5.9 (O) and pH 7.7 (O). (B) Absorption spectra of CO-haemochromogen derivatives of the products of reaction of $0.02 \mathrm{mEq} . \mathrm{Hb}, 0.1 \% \mathrm{Na}_{2} \mathrm{~S}_{2} \mathrm{O}_{4}$ and $2 \mathrm{~mm}_{-} \mathrm{H}_{2} \mathrm{O}_{2}$ at $\mathrm{pH} 5.9$ (O) and $\mathrm{pH} \mathrm{7.7} \mathrm{(O).} \mathrm{Curves} \mathrm{without} \mathrm{experimental}$ points are for $0.02 \mathrm{mEq} .-\mathrm{Hb}$ in $0.1 \% \mathrm{Na}_{2} \mathrm{~S}_{2} \mathrm{O}_{4}$ and $\mathrm{CO}$-protohaemochromogen prepared therefrom.

At $\mathrm{pH}$ 5.9, where the destruction of $\mathrm{Hb}$ is small, there is a maximum at $620 \mathrm{~m} \mu$, which is largely destroyed upon the addition of alkali and CO. The only known pigment with properties consistent with these results is sulphaemoglobin (Lemberg \& Legge, 1949).

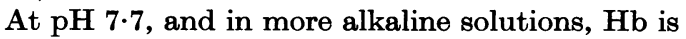
partly destroyed, and a band at $630 \mathrm{~m} \mu$ appears. This band was unaffected by treatment with alkali and $\mathrm{CO}$ (Fig. $\mathrm{l} B$ ) or by $\mathrm{CO}$ alone. Addition of alkali alone, however, resulted in a shift of this band to $617 \mathrm{~m} \mu$. Of the known pigments, choleglobin has the properties which best fit these facts (Lemberg \& Legge, 1949). The results at $\mathrm{pH} 7$ were consistent with a mixture of choleglobin and sulphaemoglobin. In all reactions, the bulk of the $\mathrm{Hb}$ was apparently unchanged. The yield of choleglobin decreased with increase of $\mathrm{pH}$ above $8 \cdot 4$, although the extent of $\mathrm{Hb}$ and protohaem destruction remained fairly constant. Detailed study of the reaction of $\mathrm{Hb}$ with $\mathrm{H}_{2} \mathrm{O}_{2}$ in a reducing medium showed that it was a complex one and composed of a number of stages, which are described below.

\section{Formation of intermediate compound}

The time course of the changes in light absorption during the reaction at $\mathrm{pH} 8.4$ from 0.2 sec. after mixing is shown in Figs. $2 A, 2 B$ and 3 . The occurrence of simultaneous discontinuities in the spectrokinetic curves of Fig. 2 shows that at least three reactions occur. The first is a rapid one, complete in 5-10 sec., in which the spectrum of the mixture changes completely, and is succeeded by a slow decline of the extinction at all wavelengths. Finally', after about 60 sec., a third slow reaction begins which results in partial reversal of the initial changes at all wavelengths except those near $630 \mathrm{~m} \mu$. The significance of these changes is brought out in Fig. 3, which gives the integrated absorption spectra at intervals after mixing. At 20 sec. the spectrum of $\mathrm{Hb}$ has been replaced by a different one, with absorption maxima at 417,545 and $582 \mathrm{~m} \mu$. This persists up to 60 sec. without significant change of shape, but with slowly decreasing intensity, and then slowly reverts to a $\mathrm{Hb}$ spectrum of reduced intensity with an additional maximum at $630 \mathrm{~m} \mu$, which may be attributed to choleglobin. This spectrum is referred to as the intermediate spectrum.

Similar spectrokinetic studies were made under various conditions : at $\mathrm{pH} 8.4$ with reactant concentrations covering the ranges $0.02-0.1 \mathrm{mEq} . \mathrm{Hb}$, $0.05-2.0 \% \quad \mathrm{Na}_{2} \mathrm{~S}_{2} \mathrm{O}_{4}$ and $0.5-5 \cdot 0 \mathrm{mM}-\mathrm{H}_{2} \mathrm{O}_{2}$; at pH 9-10 with up to 0.5 mEq.-Hb and $20 \mathrm{mM}^{-} \mathrm{H}_{2} \mathrm{O}_{2}$ (cf. Dalziel \& Ehrenberg, 1955); and at pH 5.9, 7.0 and 7.7 with $0.02 \mathrm{mEq} .-\mathrm{Hb}, 0.1 \% \mathrm{Na}_{2} \mathrm{~S}_{2} \mathrm{O}_{4}$ and $2 \mathrm{~mm}-\mathrm{H}_{2} \mathrm{O}_{2}$. In every experiment an excess of $\mathrm{Na}_{2} \mathrm{~S}_{2} \mathrm{O}_{4}$ over $\mathrm{H}_{2} \mathrm{O}_{2}$ was used, and the bulk of the $\mathrm{Hb}$ was apparently recovered unchanged. Spectrokinetic curves were recorded at the absorption maxima of $\mathrm{Hb}$, choleglobin and the intermediate spectrum and in many cases at other wavelengths. The same sequence of extinction changes occurred in all the experiments at $\mathrm{pH} 7 \cdot 7-10$. The same intermediate spectrum was obtained, and the $\epsilon_{\mathrm{mEq}}$. values were reproducible: $90 \pm 3$ at $417 \mathrm{~m} \mu, 50 \pm 4$ at $430 \mathrm{~m} \mu, 9 \cdot 0 \pm 0.4$ at $545 \mathrm{~m} \mu, 9 \cdot 6 \pm 0.4$ at $582 \mathrm{~m} \mu$. With increase of $\mathrm{pH}$ from $7 \cdot 7$ to 10 : (i) the life of the intermediate spectrum increased markedly; (ii) the rate at which it declined during its life decreased; (iii) the rate at which it was finally displaced by an $\mathrm{Hb}$ spectrum decreased. At $\mathrm{pH} 7$ similar results 
were obtained, but the intermediate spectrum had a lifetime of only a few seconds. At pH 5:9, the extinction changes were in the same sense as but smaller than those at higher $\mathrm{pH}$ values, and there was no 'steady state' in which a characteristic spectrum persisted.
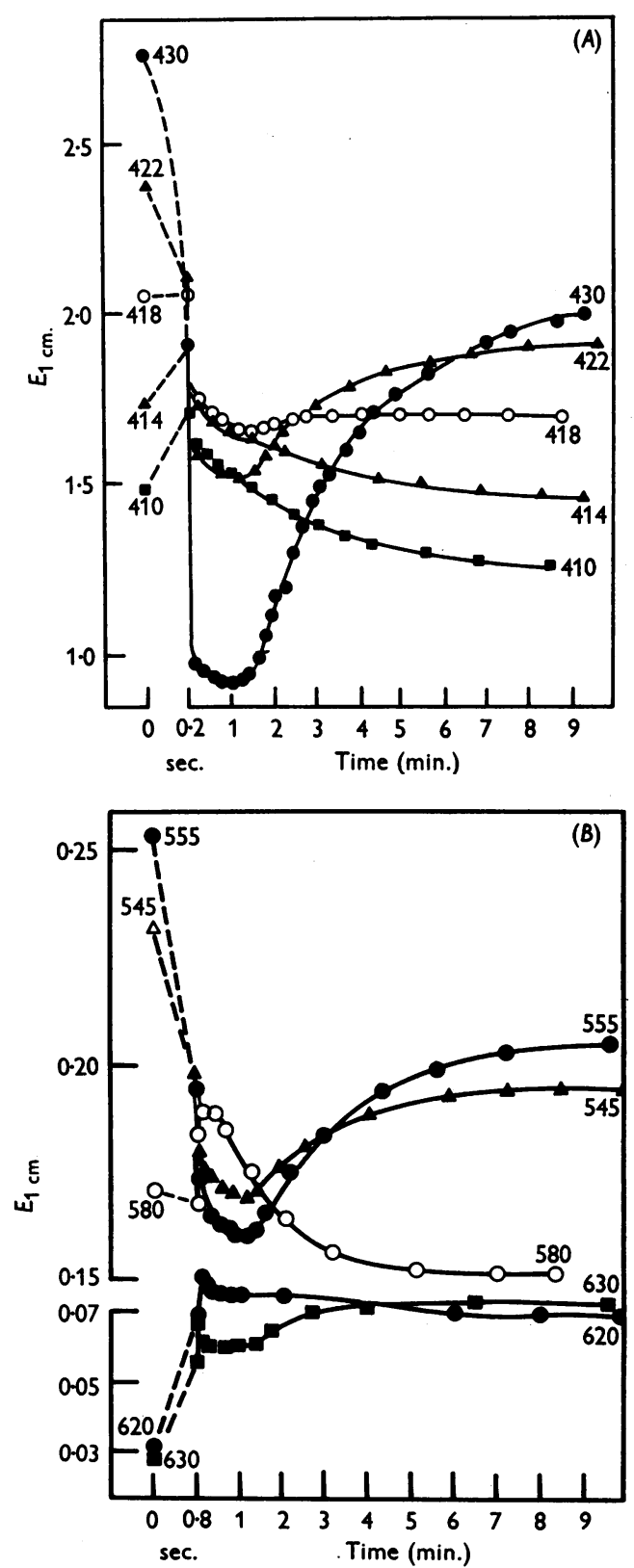

Fig. 2. $(A)$ and $(B)$ Plots of extinction against time after adding $\mathrm{H}_{2} \mathrm{O}_{2}$ to $\mathrm{Hb}$ and $\mathrm{Na}_{8} \mathrm{~S}_{2} \mathrm{O}_{4}$. Wavelengths shown on the curves are in $\mathrm{m} \mu$. The reaction mixture contained initially $0.02 \mathrm{mEq} .-\mathrm{Hb}, 0.1 \% \mathrm{Na}_{2} \mathrm{~S}_{2} \mathrm{O}_{4}$ and mM- $\mathrm{H}_{2} \mathrm{O}_{2}$, at pH 8.4.
In these experiments the decrease of the extinction at $430 \mathrm{~m} \mu$ to a reproducible level shows that $\mathrm{Hb}$ is completely displaced in the initial reaction. The symmetry, persistence and reproducibility of the maximum at $417 \mathrm{~m} \mu$ under varied conditions justifies the conclusion that this intermediate spectrum is largely due to a single $\mathrm{Hb}$ derivative, some of which undergoes degradation to products with little specific absorption, but the bulk is slowly reconverted into $\mathrm{Hb}$.

Side reaction accompanying formation of intermediate compound. There are, however, indications that more than one reaction occurs in the initial stage of the reaction. In Fig. $2 A$, the extinction at $410-416 \mathrm{~m} \mu$ increases between 0 and 0.2 sec. and then decreases to the level of the intermediate spectrum at 2-3 sec. These changes can be understood by the following experiment. A flowingreaction mixture $\left(0.2 \mathrm{mEq} .-\mathrm{Hb}, 0.1 \% \mathrm{Na}_{2} \mathrm{~S}_{2} \mathrm{O}_{4}\right.$, $3 \mathrm{~mm}-\mathrm{H}_{2} \mathrm{O}_{2}, \mathrm{pH} 8.4$ ) was observed spectroscopically in the rapid-flow apparatus; 0.09 sec. after mixing the $\mathrm{Hb}-\mathrm{Na}_{2} \mathrm{~S}_{2} \mathrm{O}_{4}$ and $\mathrm{H}_{2} \mathrm{O}_{2}$ solutions, the bands of $\mathrm{HbO}_{2}(\alpha=579 \mathrm{~m} \mu ; \beta=542 \mathrm{~m} \mu)$ were seen; from 0.3 to 0.5 sec., the single broad band of $\mathrm{Hb}$ was present but, on stopping the flow, the spectrum of the intermediate compound $(\alpha=585 ; \beta=545 \mathrm{~m} \mu)$ at once appeared.

The extinction changes in the Soret region $415 \mathrm{~m} \mu$ $\left(\lambda_{\max .} \mathrm{HbO}_{2}\right), 430 \mathrm{~m} \mu\left(\lambda_{\max .} \mathrm{Hb}\right)$ and $421 \mathrm{~m} \mu$ in the early stages of the reaction are shown in Fig. 4. $\mathrm{Hb}$ and $\mathrm{HbO}_{2}$ have the same molar extinction at $421 \mathrm{~m} \mu ; \mathrm{Hb}$ and the intermediate compound have about equal extinctions at 415 and $421 \mathrm{~m} \mu$, but at. $430 \mathrm{~m} \mu$ that of the transient compound is much smaller (cf. Figs. $2 A, 3$ ). Thus the results of Fig. 4

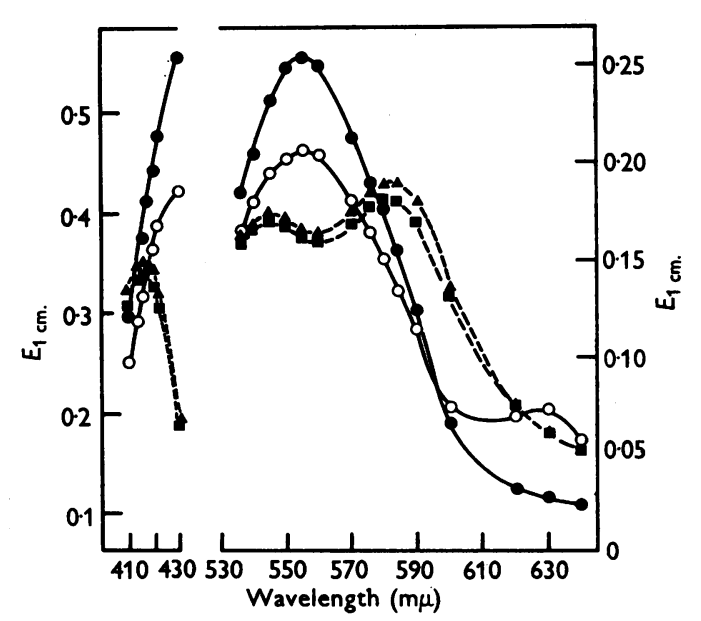

Fig. 3. Absorption spectrum of a reacting mixture of 0.02 mEq.- $\mathrm{Hb}, 0.1 \% \mathrm{Na}_{2} \mathrm{~S}_{2} \mathrm{O}_{4}$ and $\mathrm{mM}_{-}-\mathrm{H}_{2} \mathrm{O}_{2}, \mathrm{pH} \mathrm{8.4}$, at intervals after adding the $\mathrm{H}_{2} \mathrm{O}_{2}: O$, initial spectrum (Hb); $\Delta, 20$ sec.; $\square, 60$ sec.; $O, 10$ min. 
are consistent with the sequence of reactions: (1) $\mathrm{Hb} \rightarrow \mathrm{HbO}_{2}$, complete within 0.01 sec.; (2) $\mathrm{HbO}_{2} \rightarrow \mathrm{Hb}$, from 0.01 to 0.25 sec.; (3) $\mathrm{Hb} \rightarrow$ transient compound, overlapping (2) and becoming apparent as a decrease of extinction at $430 \mathrm{~m} \mu$ after $0 \cdot 3 \mathrm{sec}$.

The overall decrease of $\epsilon_{\mathrm{mEq}}$. of the reaction mixture at $430 \mathrm{~m} \mu$ from 0 to $0 \cdot 2$ sec. may be taken as a measure of the proportion of $\mathrm{Hb}$ converted into the intermediate compound in this time. The values in Table 1 for reaction mixtures of different composition suggest that at $\mathrm{pH} \mathbf{8 . 4}$ this proportion increases with the $\mathrm{H}_{2} \mathrm{O}_{2}$ concentration, but is independent of the $\mathrm{Hb}$ or $\mathrm{Na}_{2} \mathrm{~S}_{2} \mathrm{O}_{4}$ concentrations.

Lifetime of the intermediate compound. The life of the compound [measured by the time taken for the extinction at $430 \mathrm{~m} \mu$ to reach a minimum (cf. Fig. $2 A$ )], varies directly with the $\mathrm{H}_{2} \mathrm{O}_{2}$ concentration and inversely with the $\mathrm{Na}_{2} \mathrm{~S}_{2} \mathrm{O}_{4}$ and pigment concentrations, and is shortened by catalase (Table 2).

The rate at which the intermediate spectrum declined during its lifetime was not affected by a fivefold change of $\mathrm{H}_{2} \mathrm{O}_{2}$ concentration at $\mathrm{pH} 8 \cdot 4$, but increased with the $\mathrm{Na}_{2} \mathrm{~S}_{2} \mathrm{O}_{4}$ and pigment concentrations.

Haemoglobin regeneration and choleglobin formation. Except near $630 \mathrm{~m} \mu$, the initial changes of spectral absorption are largely reversed in the final stages of the reaction. At $630 \mathrm{~m} \mu$ the extinction increases during the formation of both the intermediate compound and $\mathrm{Hb}$, showing that choleglobin accumulates. The effects of varying the reactant concentrations, at $\mathrm{pH} \mathbf{8 \cdot 4}$, are represented in Table 3, where the amounts of $\mathrm{Hb}$ destroyed are expressed in terms of the percentage decrease of extinctions, $100 \Delta E / E$, at the $\mathrm{Hb}$ (or CO-haemochromogen) maxima, and the amounts of choleglobin formed in terms of the increase of light absorption of haemochromogen at $630 \mathrm{~m} \mu$. The data show that $\mathrm{Hb}$ destruction and choleglobin formation do not change in a parallel manner.

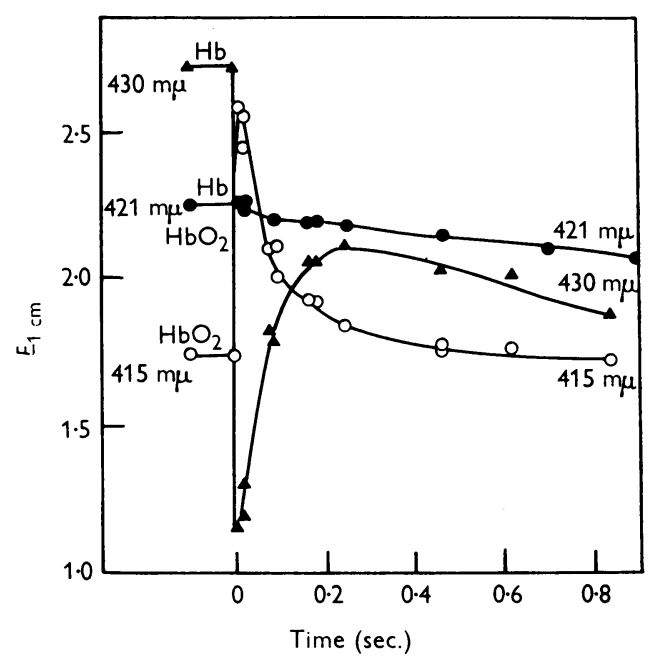

Fig. 4. Plots of extinction at 415, 421 and $430 \mathrm{~m} \mu$ against time after the addition of $\mathrm{H}_{2} \mathrm{O}_{2}$ to $\mathrm{Hb}$ and $\mathrm{Na}_{2} \mathrm{~S}_{2} \mathrm{O}_{4}$ : $0.02 \mathrm{mEq} . \mathrm{Hb}, \quad 0.1 \% \quad \mathrm{Na}_{2} \mathrm{~S}_{2} \mathrm{O}_{4}, \quad \mathrm{~mm}^{-} \mathrm{H}_{2} \mathrm{O}_{2}, \quad \mathrm{pH} 8.4$, showing the early stages of the reaction.

Table 1. Extinction coefficients $\left(\boldsymbol{\epsilon}_{\mathrm{mEq}}\right)$ after the addition of hydrogen peroxide to haemoglobindithionite solutions

Extinction coefficients $\left(\epsilon_{\mathrm{mEq}}\right)$ were measured at $430 \mathrm{~m} \mu$, $0 \cdot 2$ sec. after the addition of hydrogen peroxide to haemoglobin-dithionite solutions, at $\mathrm{pH} \mathbf{8} \cdot 4$. The rate of formation of the transient compound $\left(\epsilon_{\mathrm{mEq}}=50\right)$ from haemoglobin $\left(\epsilon_{\mathrm{mEq}}=135\right)$ with various reactant concentrations is shown.

\begin{tabular}{|c|c|c|c|}
\hline \multicolumn{3}{|c|}{ Composition of reaction mixture } & \\
\hline $\begin{array}{c}\mathrm{Hb} \\
\text { (m-equiv./l.) }\end{array}$ & $\begin{array}{c}\mathrm{Na}_{2} \mathrm{~S}_{2} \mathrm{O}_{4} \\
\text { (g./ } / 100 \text { ml.) }\end{array}$ & $\begin{array}{c}\mathrm{H}_{2} \mathrm{O}_{2} \\
\text { (m-moles/l.) }\end{array}$ & $\boldsymbol{\epsilon}_{\mathrm{mEq}}$. \\
\hline $0 \cdot 10$ & $0 \cdot 10$ & $1 \cdot 0$ & 102 \\
\hline 0.02 & $0 \cdot 10$ & $1 \cdot 0$ & 95 \\
\hline 0.02 & $0 \cdot 20$ & $1 \cdot 0$ & 100 \\
\hline 0.02 & $0 \cdot 20$ & $5 \cdot 0$ & 64 \\
\hline $0 \cdot 02$ & $0 \cdot 80$ & $5 \cdot 0$ & 66 \\
\hline
\end{tabular}

Table 2. Effect of reactant concentrations and catalase on the life of the transient spectrum at $\mathrm{pH} 8 \cdot 4$

\begin{tabular}{|c|c|c|c|c|}
\hline \multicolumn{4}{|c|}{ Composition of reaction mixture } & \multirow{2}{*}{$\begin{array}{l}\text { Life of } \\
\text { transient } \\
\text { spectrum } \\
\text { (sec.) }\end{array}$} \\
\hline$\frac{\mathrm{Hb}}{\text { (m-equiv./l.) }}$ & $\begin{array}{c}\mathrm{Na}_{2} \mathrm{~S}_{2} \mathrm{O}_{4} \\
\text { (g./100 ml.) }\end{array}$ & $\begin{array}{c}\mathrm{H}_{2} \mathrm{O}_{2} \\
\text { (m-moles/l.) }\end{array}$ & Catalase & \\
\hline 0.02 & $0 \cdot 1$ & $0 \cdot 5$ & Absent & 28 \\
\hline 0.02 & $0 \cdot 1$ & $1 \cdot 0$ & Absent & 60 \\
\hline 0.02 & $0 \cdot 1$ & $2 \cdot 0$ & Absent & 160 \\
\hline 0.02 & $0 \cdot 2$ & $1 \cdot 0$ & Absent & 30 \\
\hline 0.02 & 0.2 & $5 \cdot 0$ & Absent & 111 \\
\hline 0.02 & $0 \cdot 8$ & $5 \cdot 0$ & Absent & 33 \\
\hline 0.02 & 0.05 & $1 \cdot 0$ & Absent & 210 \\
\hline 0.02 & $0 \cdot 8$ & 1.0 & Absent & 15 \\
\hline 0.05 & $0 \cdot 1$ & 1.0 & Absent & 24 \\
\hline $0 \cdot 10$ & $0 \cdot 1$ & 1.0 & Absent & 15 \\
\hline 0.02 & $0 \cdot 1$ & $1 \cdot 0$ & Present & 15 \\
\hline 0.02 & 0.1 & $2 \cdot 0$ & Present & 21 \\
\hline $0 \cdot 10$ & $0 \cdot 1$ & $2 \cdot 0$ & Present & 6 \\
\hline
\end{tabular}


Table 3. Extinction changes $(\Delta E)$ accompanying the overall reaction of haemoglobin, dithionite and hydrogen peroxide in various concentrations at $\mathrm{pH} 8 \cdot 4$

\begin{tabular}{ccc}
\multicolumn{3}{c}{ Composition of reaction mixture } \\
$\begin{array}{c}\mathrm{Hb} \\
\text { (m-equiv./l.) }\end{array}$ & $\begin{array}{c}\mathrm{Na}_{2} \mathrm{~S}_{2} \mathrm{O}_{4} \\
(\mathrm{~g} . / 100 \mathrm{ml} .)\end{array}$ & $\begin{array}{c}\mathrm{H}_{2} \mathrm{O}_{2} \\
\text { (m-moles/l.) }\end{array}$ \\
0.02 & 0.1 & 0.5 \\
0.02 & 0.1 & 1.0 \\
0.02 & 0.1 & 2.0 \\
0.02 & 0.2 & 1.0 \\
0.02 & 0.2 & 5.0 \\
0.02 & 0.05 & 1.0 \\
0.02 & 0.4 & 1.0 \\
0.02 & 0.8 & 1.0 \\
0.02 & 1.6 & 1.0 \\
& & \\
0.02 & & \\
0.05 & 0.1 & 1.0 \\
0.10 & 0.1 & 1.0 \\
0.10 & 0.1 & 1.0 \\
& 0.1 & 2.0
\end{tabular}

$\begin{array}{cc}\begin{array}{c}\text { Products } \\ (100 \Delta E / E \text { at }\end{array} & \begin{array}{c}\text { CO-haemo- } \\ \text { chromogens } \\ (100 \Delta E \text { at } \\ 430 \mathrm{~m} \mu)\end{array} \\ \mathbf{6 3 0 \mathrm { m } \mu )} \\ 15 & 3 \\ 20 & 2 \\ 29 & 3 \\ 16 & 5 \\ 37 & 5 \\ 31 & 2 \\ 16 & 6 \\ 16 & 7 \\ 18 & 8 \\ (100 \Delta E / E \text { at } & \\ 555 \mathrm{~m} \mu) & \\ 18 & 2 \\ 13 & 9 \\ 10 & 20 \\ 17 & 21\end{array}$

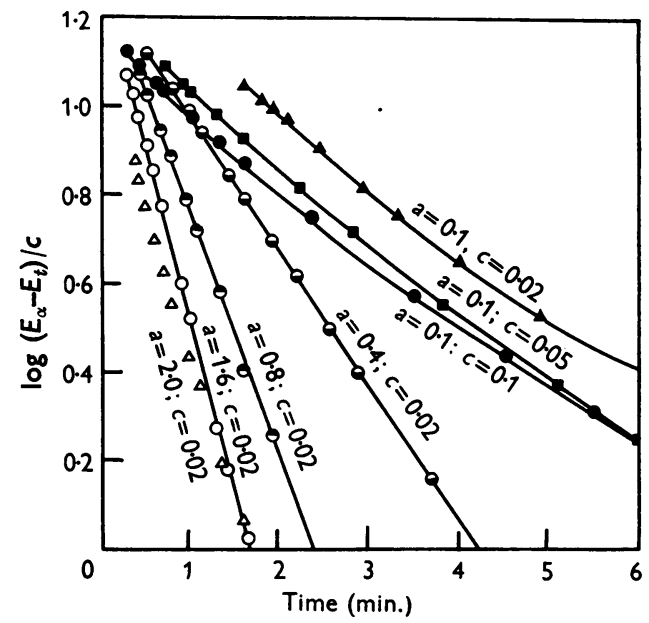

Fig. 5. Effect of $\mathrm{Na}_{2} \mathrm{~S}_{2} \mathrm{O}_{4}$ concentration on the rate of reversion of the transient compound to $\mathrm{Hb}$ at $\mathrm{pH} \mathrm{8.5}$. $E_{\alpha}-E_{t}$ is approximately proportional to the concentration of the transient compound; $c=$ initial $\mathrm{Hb}$ concentration (mEq.) and $a=\mathrm{Na}_{2} \mathrm{~S}_{2} \mathrm{O}_{4}$ concentration (\%); $\mathrm{H}_{2} \mathrm{O}_{2}$ concentration was $\mathrm{mM}$ in all experiments.

In the Soret region, where choleglobin does not absorb appreciably (Lemberg, Holden, Legge \& Lockwood, 1942), the final extinction changes are consistent with the reconversion of a single com. pound, characterized by the $417 \mathrm{~m} \mu$ maximum, into $\mathrm{Hb}$ (Figs. $2 A, 3$ ). The rates of this reaction with various reactant concentrations at $\mathrm{pH} 8.4$ are shown in Fig. 5. The plots are linear except with the lowest $\mathrm{Na}_{2} \mathrm{~S}_{2} \mathrm{O}_{4}$ concentrations. The slope is independent of the pigment concentration and increases with the $\mathrm{Na}_{2} \mathrm{~S}_{2} \mathrm{O}_{4}$ concentration up to $1.6 \%$. The half-reaction time calculated from the slopes de. creases from 113 sec. with $0 \cdot 1 \% \mathrm{Na}_{2} \mathrm{~S}_{2} \mathrm{O}_{4}$, to 25 sec. with $1.6 \% \mathrm{Na}_{2} \mathrm{~S}_{2} \mathrm{O}_{4}$.

In Fig. $6 A, B, C$, the extinction changes at the visible maxima of $\mathrm{Hb}$, the intermediate compound and choleglobin during the later stages of the reaction are shown. At different $\mathrm{pH}$ values the curves for 545 and $555 \mathrm{~m} \mu$ accurately reflect the time course of the concomitant extinction changes at $430 \mathrm{~m} \mu$ (not shown). The end of the life of the intermediate spectrum is indicated by simultaneous minima in the curves for these three wavelengths, i.e. $2.8 \mathrm{~min}$. at $\mathrm{pH} 8.5,1.3 \mathrm{~min}$. at $\mathrm{pH} 7.8$ and $0.5 \mathrm{~min}$. at $\mathrm{pH} 7.0$, after which the extinction increases again. These final increases to stable values occur at about the same rate and are complete in the same times at all three wavelengths. These results support the conclusion that the Soret maximum at $417 \mathrm{~m} \mu$ and the maximum at $545 \mathrm{~m} \mu$ in the intermediate spectrum are due to a single derivative, and that the final extinction changes in these spectral regions represent the reconversion of this substance into $\mathrm{Hb}$.

At $580 \mathrm{~m} \mu$ the formation of the intermediate spectrum is associated with a sharp increase of extinction. In the experiment at $\mathrm{pH} 8.5$ (Fig. $6 \mathrm{~A}$ ) the extinction at this wavelength subsequently decreases at the same rate as at other wavelengths, whilst the intermediate spectrum persists undistorted but with diminishing intensity. There is an inflexion at $3 \mathrm{~min}$. and the subsequent decrease of extinction occurs at the same rate as the increases at 545,555 and $430 \mathrm{~m} \mu$. At pH 8.5 therefore the intermediate spectrum apparently behaves as a single entity. At $\mathrm{pH} \mathrm{7.8}$ and 7 the extinction change at $580 \mathrm{~m} \mu$ follow the same general course as at $\mathrm{pH} 8.5$ at an increased rate. At pH 7 (Fig. $6 \mathrm{C}$ ) the initial rise in extinction is less and this may be due to the instability of the intermediate at this $\mathrm{pH}$. 


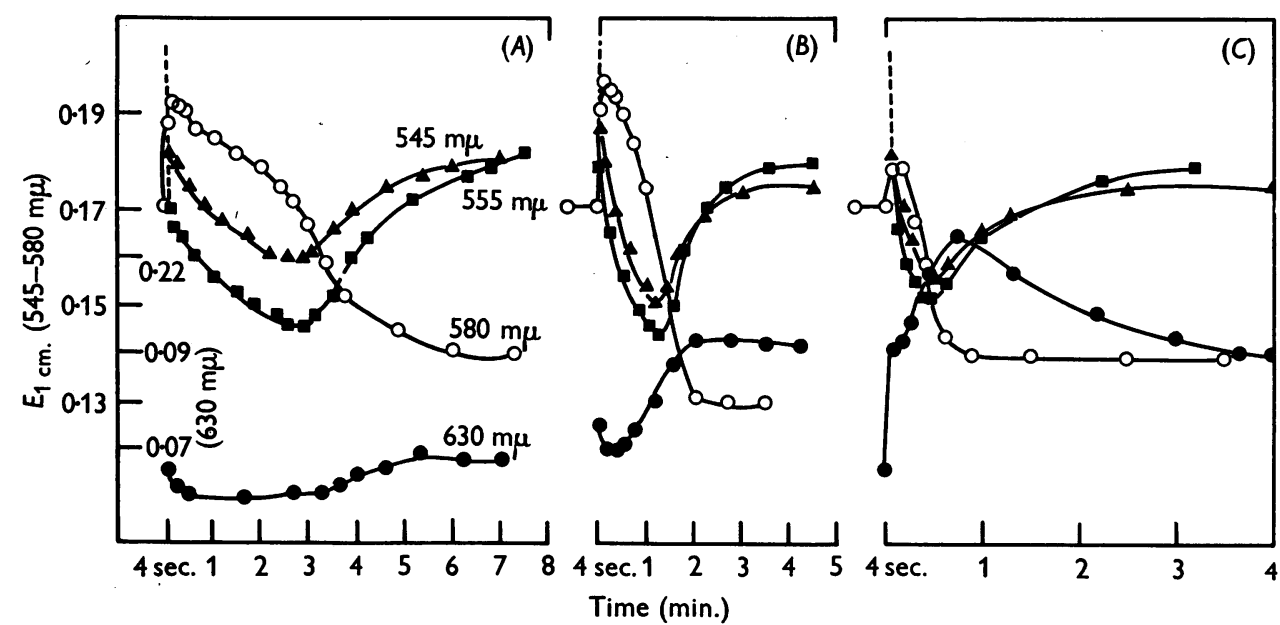

Fig. 6. Spectrokinetic curves for 545, 555, 580 and $630 \mathrm{~m} \mu$, for the reaction of $0.02 \mathrm{mEq} .-\mathrm{Hb}, 0 \cdot 1 \% \mathrm{Na}_{2} \mathrm{~S}_{2} \mathrm{O}_{4}$ and $2 \mathrm{mM}_{-} \mathrm{H}_{2} \mathrm{O}_{2}$. (A) $\mathrm{pH} 8 \cdot 5 ;(B) \mathrm{pH} 7 \cdot 8 ;(C) \mathrm{pH} 7 \cdot 0$.

A discrepancy does arise in that a stable extinction at $580 \mathrm{~m} \mu$ is reached in $2 \mathrm{~min}$. at $\mathrm{pH} 7.8$ and in $1 \mathrm{~min}$. at $\mathrm{pH} 7$, although at other wavelengths the extinction is still rapidly increasing at these times. A stable $\mathrm{Hb}$ spectrum is not obtained until after $5 \mathrm{~min}$. at $\mathrm{pH} 7.8$ and $3 \mathrm{~min}$. at $\mathrm{pH} 7$. Therefore the regeneration of $\mathrm{Hb}$ cannot be wholly responsible for

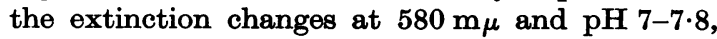
and the intermediate spectrum cannot be said to behave as an entity throughout the reaction, as it appears to do at $\mathrm{pH} \mathbf{8 . 5}$.

There is a correlation between extinction changes at 630 and $580 \mathrm{~m} \mu$ at all three $\mathrm{pH}$ values. At $630 \mathrm{~m} \mu$ the extinction reaches a maximum in $6 \mathrm{~min}$. at $\mathrm{pH} 8.5,2 \mathrm{~min}$. at $\mathrm{pH} 7.8$ and $1 \mathrm{~min}$. at $\mathrm{pH} \mathrm{7,} \mathrm{and} \mathrm{the} \mathrm{extinction} \mathrm{at} 580 \mathrm{~m} \mu$ falls to a constant value in the same times. These results suggest that the maximum at $582 \mathrm{~m} \mu$ in the intermediate spectrum may be due partly to a choleglobin precursor.

The final decrease of extinction at $630 \mathrm{~m} \mu$ in the reaction at $\mathrm{pH} 7$ (Fig. $6 C$ ), which also occurs to a small degree at pH $7 \cdot 8$, may represent the further degradation of choleglobin or the regeneration of $\mathrm{Hb}$.

Effect of carbon monoxide on the reaction. Hydrogen peroxide does not affect the spectrum of carboxyhaemoglobin $\left(\mathrm{HbCO}\right.$ ) in $\mathrm{Na}_{2} \mathrm{~S}_{2} \mathrm{O}_{4}$ solution at $\mathrm{pH} 6$ and 8.5, and saturation of $\mathrm{H}_{2} \mathrm{O}_{2}$ solution with $\mathrm{CO}$ largely inhibited its reaction with $\mathrm{Hb}$ in $\mathrm{Na}_{2} \mathrm{~S}_{2} \mathrm{O}_{4}$. The passing of $\mathrm{CO}$ into a $\mathrm{Hb}-\mathrm{Na}_{2} \mathrm{~S}_{2} \mathrm{O}_{4}$ solution immediately after the addition of $\mathrm{H}_{2} \mathrm{O}_{2}$ during the life of the intermediate spectrum was studied.

Solutions of $0.02 \mathrm{mEq}$.- $\mathrm{Hb}$ in $0.05 \% \mathrm{Na}_{2} \mathrm{~S}_{2} \mathrm{O}_{4}$ and mM- $\mathrm{H}_{2} \mathrm{O}_{2}$, both buffered at $8 \cdot 5$, were mixed by passage through the rapid-flow apparatus; under these conditions the lifetime of the intermediate

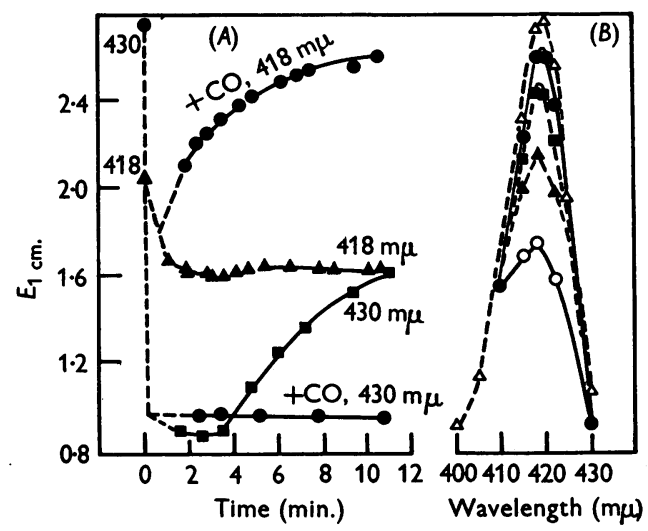

Fig. 7. Effect of carbon monoxide on the reaction of $\mathrm{H}_{2} \mathrm{O}_{2}$ with $\mathrm{Hb}$ in dithionite solution. Hydrogen peroxide was added at time 0 and carbon monoxide passed from 10 to $25 \mathrm{sec}$. Initial concentrations: $0.02 \mathrm{mEq} .-\mathrm{Hb}, 0.05 \%$

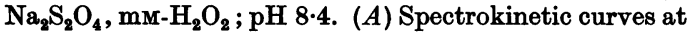
418 and $430 \mathrm{~m} \mu$ with and without $\mathrm{CO}$; $(B)$ absorption spectra of reacting mixture in Soret region: $O, 10 \mathrm{sec}$. (before CO); $\Delta, 2$ min.; $\square, 5$ min.; O, 10 min.; $\triangle, 1 \mathrm{hr}$.

compound was $3 \mathrm{~min}$. A portion of the mixture was treated with CO during the period 10-25 sec. after mixing, and transferred to an optical cell which was sealed with liquid paraffin and a coverslip. Change of the extinctions at three wavelengths with time was followed in the sample; similar measurements were made on other samples at other wavelengths. The features of the reaction described below have also been observed in the spectroscope with $0.1 \mathrm{mEq} \cdot-\mathrm{Hb}, 0.1 \% \mathrm{Na}_{2} \mathrm{~S}_{2} \mathrm{O}_{4}$ and $2 \mathrm{~mm}-\mathrm{H}_{2} \mathrm{O}_{2}$ at $\mathrm{pH} 9 \cdot 5$.

The spectrokinetic curves at 418 and $430 \mathrm{~m} \mu$, with and without $\mathrm{CO}$ treatment (Fig. $7 A$ ), show

Bioch. 1957, 67 
that on the introduction of $\mathrm{CO}$ a new reaction accompanied by an increase of extinction at $418 \mathrm{~m} \mu$ begins at once. During this reaction, the Soret maximum of the intermediate spectrum (Fig. $7 B$ ) is gradually converted into a much more intense maximum at $419 \mathrm{~m} \mu$. These changes can be accounted for by a single reaction, namely the conversion of a derivative characterized by the maximum at $417 \mathrm{~m} \mu$ into $\mathrm{HbCO}, \lambda_{\max } 419 \mathrm{~m} \mu$, with a half-period of about $2.5 \mathrm{~min}$.

The corresponding changes in the visible region up to $10 \mathrm{~min}$. are shown in Fig. $8 A$ and $B$. The initial data in these diagrams correspond to the intermediate spectrum obtained in control experiments. At 535-575 $\mathrm{m} \mu$, the extinction changes after the introduction of $\mathrm{CO}$ occur at about the same rate as those in the Soret region, and are again consistent with the formation of $\mathrm{HbCO}\left(\lambda_{\max } .539\right.$, $568 \mathrm{~m} \mu$ ) from the intermediate compound. Another reaction also occurs; a pronounced peak appears at $600 \mathrm{~m} \mu$, reaches its greatest intensity in $2 \mathrm{~min}$. and then declines. The subsequent spectral changes at $580-640 \mathrm{~m} \mu$, from $10 \mathrm{~min}$. onwards, are shown in Fig. $8 C$. In the course of several hours, the maximum at $600 \mathrm{~m} \mu$ declines whilst a new peak develops at $628 \mathrm{~m} \mu$. Throughout this slow reaction, the absorption spectrum at shorter wavelengths remains almost unchanged.

These results show that in the presence of $\mathrm{CO}$ a new unstable intermediate, $\lambda_{\max } 600 \mathrm{~m} \mu$, is formed in considerable amount during the first $2 \mathrm{~min}$., and is then very slowly converted into carboxycholeglobin, $\lambda_{\max } 628 \mathrm{~m} \mu$, and the regenerated $\mathrm{Hb}$ converted into $\mathrm{HbCO}, \lambda_{\max } 419,539,568 \mathrm{~m} \mu$. The spectral absorption of the mixture at intervals during this latter reaction (Fig. $8 C$ ) shows an isosbestic point at $614 \mathrm{~m} \mu$ which suggests that the conversion of the new intermediate into carboxycholeglobin is quantitative. At the start of this reaction, that is when the maximum at $600 \mathrm{~m} \mu$ has reached its greatest intensity, $E_{600 \mathrm{~m} \mu}$ is 0.200 and $E_{630 \mathrm{~m} \mu}$ is 0.060 . The differences between these values and the measured extinctions $E_{t}$, at various later times (Table 4), are the same for both wavelengths, and therefore the molar-extinction coefficients of the two substances at their respective maxima are about equal. Since the reaction is not accompanied by significant spectral changes in the regions 536-580 and $400-430 \mathrm{~m} \mu$, where typical carboxyhaemoglobin maxima persist unchanged, it also follows that both substances have little specific absorption in these regions.

At intervals during this slow formation of $\mathrm{CO}$ choleglobin from the new intermediate, samples of the reaction mixture were converted into the CO-haemochromogen derivatives. From $16 \mathrm{~min}$. after the introduction of $\mathrm{CO}$ the absorption spectra of these derivatives remained constant, and indicated a mixture of proto- and cholehaemochromogen.

Table 4. Extinction changes at 600 and $630 m \mu$ during the formation of carboxycholeglobin (cf. Fig. $8 C$ )

$\begin{array}{ccc}\text { Time } & \left(0.200-E_{t}\right), & \left(E_{t}-0.06\right), \\ (\mathrm{hr} .) & 600 \mathrm{~m} \mu & 630 \mathrm{~m} \mu \\ 0.85 & 0.026 & 0.025 \\ 1.75 & 0.046 & 0.044 \\ 2.75 & 0.058 & 0.056 \\ 3.75 & 0.074 & 0.072 \\ 18.0 & 0.113 & 0.111 \\ 24.0 & 0.115 & 0.114\end{array}$
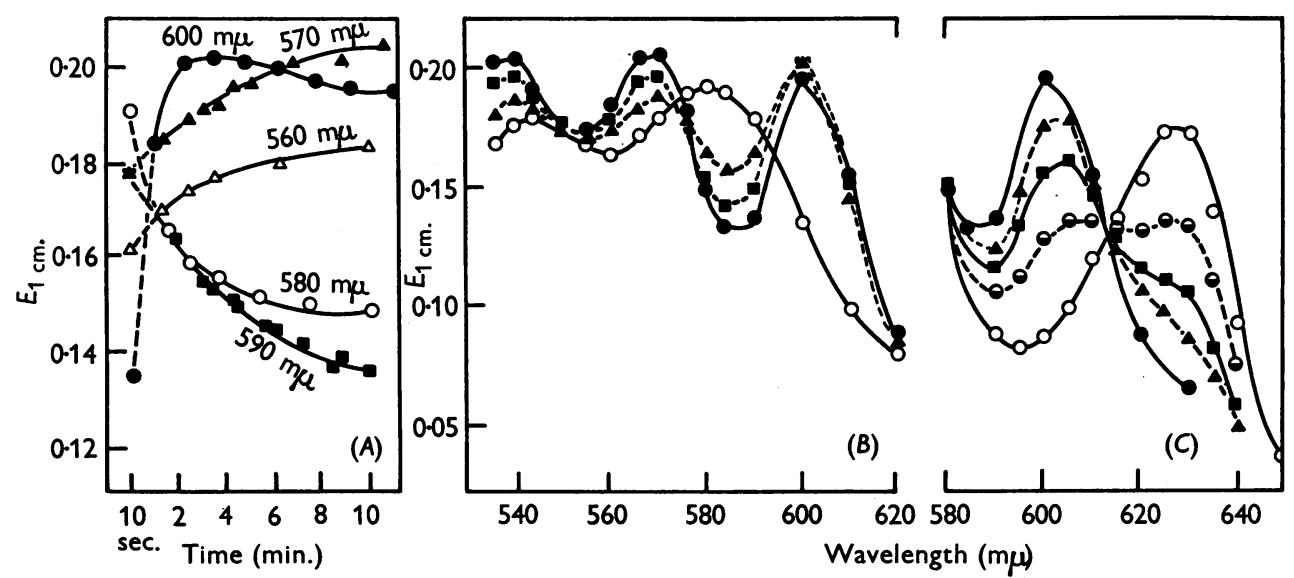

Fig. 8. Effect of carbon monoxide on the reaction of $\mathrm{H}_{2} \mathrm{O}_{2}$ with $\mathrm{Hb}$ in dithionite solution; conditions were as for Fig. 7 . (A) Spectrokinetic curves from 10 sec. after addition of peroxide; $\mathrm{CO}$ was passed during the period 10-25 sec.;

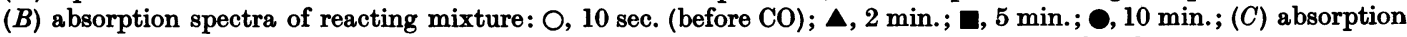
spectra of reacting mixture: $\bullet, 10$ min.; $\triangle, 52$ min.; $\square, 105$ min.; $\ominus, 225$ min.; $\bigcirc, 18$ and $24 \mathrm{hr}$. 
Comparison of the absorption spectra of the final products of the reactions with and without $\mathrm{CO}$ treatment, and of CO-haemochromogen derivatives of the products, showed that CO greatly increased the choleglobin yield, but did not significantly affect the amount of $\mathrm{Hb}$ destroyed.

Effect of hydrosulphide upon the reaction. The reaction of $\mathrm{Hb}$ in $\mathrm{Na}_{2} \mathrm{~S}_{2} \mathrm{O}_{4}$ solution with $\mathrm{H}_{2} \mathrm{O}_{2}$ at acid $\mathrm{pH}$ produced a pigment with properties akin to those of sulphaemoglobin. It is known that $\mathrm{H}_{2} \mathrm{O}_{2}$ and sulphides react with $\mathrm{Hb}$ in $\mathrm{Na}_{2} \mathrm{~S}_{2} \mathrm{O}_{4}$ to form sulphaemoglobin in amounts greater in acid conditions than in alkaline (Michel, 1938). In the reaction under investigation, $\mathrm{H}_{2} \mathrm{O}_{2}$ is one of the reactants and the other, $\mathrm{Na}_{2} \mathrm{~S}_{2} \mathrm{O}_{4}$, is a possible source of $\mathrm{H}_{2} \mathrm{~S}$ (Bassett \& Durrant, 1927). The effect of hydrosulphide on the reaction was therefore studied.

Experiments were made with $0.1 \mathrm{mEq} .-\mathrm{Hb}$ solutions in $0.1 \% \mathrm{Na}_{2} \mathrm{~S}_{2} \mathrm{O}_{4}$ at $\mathrm{pH} 6,8.5$ and 9.5 , and hydrosulphide (NaSH), which was a $0.5 \mathrm{~N}-\mathrm{NaOH}$ solution saturated with $\mathrm{H}_{2} \mathrm{~S}$. The following observations were made with the reversion spectroscope.

(i) At either $\mathrm{pH} 8.5$ or 9.5 (a) $0.1 \mathrm{ml}$. of $\mathrm{H}_{2} \mathrm{O}_{2}$ was added to $10 \mathrm{ml}$. of $\mathrm{Hb}$ solution. The two bands of the intermediate spectrum, at 588 and $548 \mathrm{~m} \mu$, appeared at once, persisted for $1 \mathrm{~min}$. and then gradually fused; the products showed a broad haemoglobin band at $560 \mathrm{~m} \mu$ and a faint band at $630 \mathrm{~m} \mu$. (b) When $0 \cdot 1,0.3$ or $0.5 \mathrm{ml}$. of $\mathrm{NaSH}$ was added to $10 \mathrm{ml}$. of $\mathrm{Hb}$ solution a faint band appeared at once at $620 \mathrm{~m} \mu$, but the $\mathrm{Hb}$ band remained unaltered. (c) When $0.1 \mathrm{ml}$. of $\mathrm{H}_{2} \mathrm{O}_{2}$ was added to $10 \mathrm{ml}$. of $\mathrm{Hb}$ solution, followed immediately by $0.1 \mathrm{ml}$. of NaSH, a strong band appeared at once at $620 \mathrm{~m} \mu$ and distinct bands at 575 and $541 \mathrm{~m} \mu$. There was no change in $10 \mathrm{~min}$. and addition of $30 \mathrm{mg}$. of $\mathrm{Na}_{2} \mathrm{~S}_{2} \mathrm{O}_{4}$ caused no change in $5 \mathrm{~min}$. The solution was red-brown by transmitted light, green-brown by reflected light. (d) In a similar experiment, the NaSH was added 90 sec. after the $\mathrm{H}_{2} \mathrm{O}_{2}$, when the intermediate spectrum was giving way to a $\mathrm{Hb}$ spectrum. Immediate observation showed a $\mathrm{Hb}$ band and a fairly strong band at $620 \mathrm{~m} \mu$, weaker than that obtained in (c), much stronger than that obtained in $(b) .(e) 0.1 \mathrm{ml}$. of $\mathrm{NaSH}$ was added to $10 \mathrm{ml}$. of $\mathrm{Hb}$ solution, and after rapid observation of the band formed at $620 \mathrm{~m} \mu$, cf. (b), $0.1 \mathrm{ml}$. of $\mathrm{H}_{2} \mathrm{O}_{2}$ was added. Immediate observations showed that the band at $620 \mathrm{~m} \mu$ had become broader and stronger, and its centre had shifted to $623 \mathrm{~m} \mu$; and that the haemoglobin band had been replaced by bands at 575 and

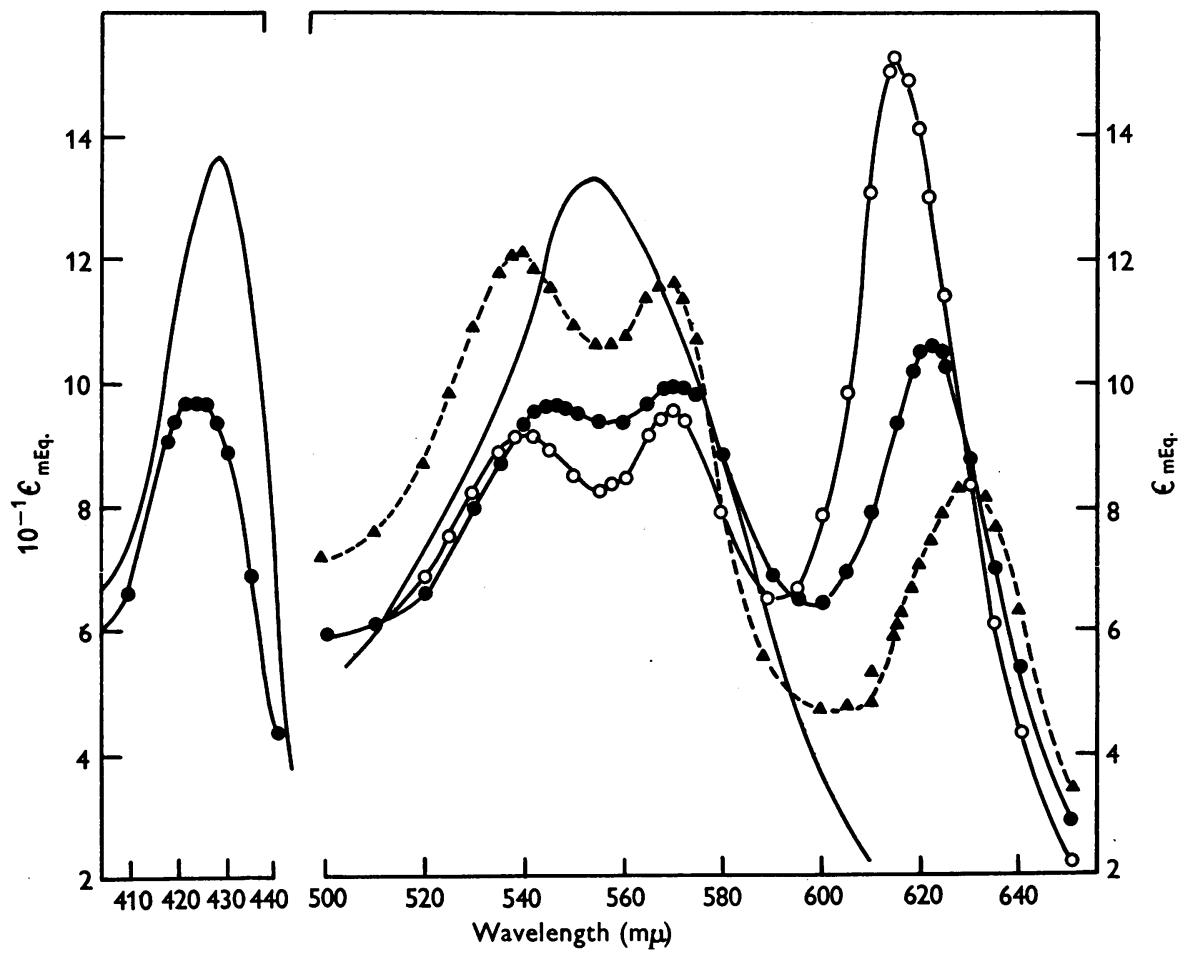

Fig. 9. Absorption spectrum of the products and derivatives of the reaction of $0 \cdot 1 \mathrm{mEq} \cdot-\mathrm{Hb}, 0 \cdot 1 \% \mathrm{Na}_{2} \mathrm{~S}_{2} \mathrm{O}_{4}, \mathrm{~mm}^{-} \mathrm{H}_{2} \mathrm{O}_{2}$ and $5 \mathrm{~mm}-\mathrm{NaSH}$ at $\mathrm{pH} \mathrm{8.5}$. The ordinates are milliequivalent extinction coefficients referred to the initial $\mathrm{Hb}$ concentration. - $\mathrm{Hb}$; O, products; $\mathrm{O}$, products treated with $\mathrm{CO} ; \Delta, \mathrm{CO}$-haemochromogen derivatives of products. 
$541 \mathrm{~m} \mu$. There was no further change after several minutes.

(ii) At pH 6. (a) $0.1 \mathrm{ml}$. of $\mathrm{H}_{2} \mathrm{O}_{2}$ was added to $10 \mathrm{ml}$. of $\mathrm{Hb}$ solution. A distinct band appeared at once at $626 \mathrm{~m} \mu$, but the $\mathrm{Hb}$ band remained unchanged: the intermediate spectrum was not observed. (b) The addition of $0.1 \mathrm{ml}$. of NaSH to the products of $(a) 1 \mathrm{~min}$. after the original addition of $\mathrm{H}_{2} \mathrm{O}_{2}$ had no effect. (c) The addition of $0.1 \mathrm{ml}$. of $\mathrm{NaSH}$ to $10 \mathrm{ml}$. of $\mathrm{Hb}$ solution had no effect.

The absorption spectra of products obtained as in (i) (c) above consistently showed a pronounced peak at $622 \mathrm{~m} \mu$, shifted to $616 \mathrm{~m} \mu$ by CO (Fig. 9), but its intensity varied by about $30 \%$ in different preparations under apparently identical conditions. Two maxima at 545 and $570 \mathrm{~m} \mu$ were usually formed, but were replaced in the course of $30 \mathrm{~min}$. or more by a broad maximum at $555 \mathrm{~m} \mu$. In some preparations a single broad maximum at $555 \mathrm{~m} \mu$ was obtained at once; there was no correlation between the appearance of the two bands in the green and the intensity of the maximum at $622 \mathrm{~m} \mu$. There was no sign of an inflexion at $630 \mathrm{~m} \mu$ in the product spectrum, such as would be expected if appreciable amounts of choleglobin were present, yet in the absorption spectrum of CO-haemochromogen derivatives prepared from the fresh products (Fig. 9) a pronounced maximum at $630 \mathrm{~m} \mu$ suggests the presence of cholehaem, and the depression of the CO-protohaemochromogen maxima (initial values $\epsilon_{\mathrm{mEq} .}=14.4$ at $539 \mathrm{~m} \mu, 14.0$ at $569 \mathrm{~m} \mu$ ) shows that some protohaem destruction has occurred.

\section{Reaction of hydrogen peroxide with myoglobin in dithionite solution}

The reaction was studied by spectrokinetic measurements at 13 wavelengths in the region of

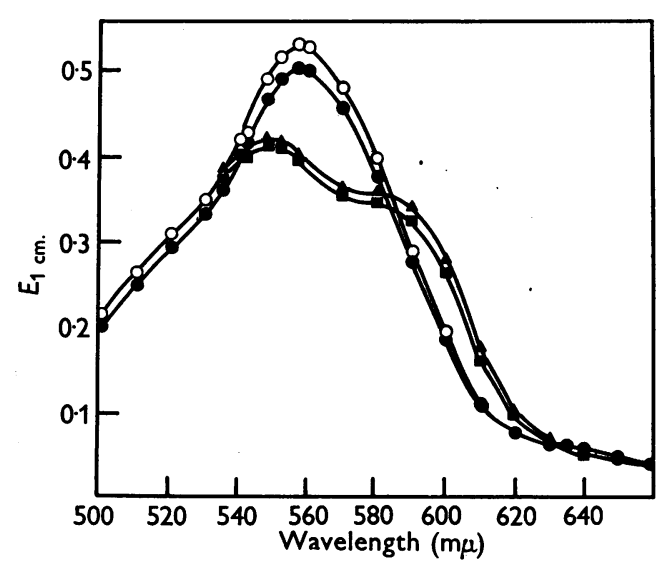

Fig. 10. Spectral absorption of a reacting mixture of $0.04 \mathrm{mEq}$.-myoglobin, $0.1 \% \mathrm{Na}_{2} \mathrm{~S}_{2} \mathrm{O}_{4}$ and $2 \mathrm{mM}_{-} \mathrm{H}_{2} \mathrm{O}_{2}$, $\mathrm{pH} 9.5$, at intervals after the addition of peroxide: $O$, myoglobin, $t=0$; $\Delta, 1$ min.; $\square, 10$ min.; $O$, products.
536-640 $\mathrm{m} \mu$ from $1 \mathrm{~min}$. after the addition of peroxide until a stable spectrum was obtained. Within 1 min. of the addition of $\mathrm{H}_{2} \mathrm{O}_{2}$, the myoglobin curve was replaced by a new spectrum with a maximum at $548 \mathrm{~m} \mu, \epsilon_{\mathrm{mM}}=10 \cdot 5$, and a pronounced shoulder at $585 \mathrm{~m} \mu, \epsilon_{\mathrm{mM}}=9 \cdot 0$, which persisted without change of shape but with very slowly decreasing intensity for $10 \mathrm{~min}$. and then gradually gave way to a myoglobin curve of slightly reduced intensity (Fig. 10). The intermediate spectrum is indistinguishable from that of metmyoglobin$\mathrm{H}_{2} \mathrm{O}_{2}$, and the extinction coefficients indicate that all the myoglobin is converted into this derivative (cf. George \& Irvine, 1951). There is no evidence of the presence of cholemyoglobin or any other coloured degradation product. The absorption spectrum of CO-haemochromogen derivatives of the products confirmed that a small proportion of the myoglobin was destroyed in the overall reaction by degradation of the protohaem, but there was no evidence of the presence of any other haem derivatives.

The effect of passing $\mathrm{CO}$ into a reacting mixture of myoglobin, dithionite and peroxide, immediately after the addition of peroxide and during the life of the intermediate spectrum, was observed in the spectroscope. The two bands shifted slightly, to 579 and $541 \mathrm{~m} \mu$, consistent with the formation of carboxymyoglobin, but there was no evidence of the formation of any other pigment.

\section{DISCUSSION}

The results of the experiments confirm the mechanism proposed for the action of oxygen on solutions of $\mathrm{Hb}$ containing $\mathrm{Na}_{2} \mathrm{~S}_{2} \mathrm{O}_{4}$ (Dalziel \& O'Brien, 1957). They point to the formation of an unstable derivative of $\mathrm{Hb}$ on the addition of hydrogen peroxide, the existence of which is substantiated by magnetokinetic measurements (Dalziel \& Ehrenberg, 1955). The substance with a Soret band at $417 \mathrm{~m} \mu$ and low paramagnetic susceptibility appears to be formed directly from $\mathrm{Hb}$ at a rate which grows with the hydrogen peroxide concentration. It has a lifetime which varies directly with the peroxide concentration and inversely with the dithionite concentration, and is shortened by catalase; it is largely reconverted into $\mathrm{Hb}$ at a rate increasing with the $\mathrm{Na}_{2} \mathrm{~S}_{2} \mathrm{O}_{4}$ concentration up to a certain limit. It is probably formed by oxidation of, or co-ordination of an oxidizing group with, the iron atoms of $\mathrm{Hb}$ and survives during the life of hydrogen peroxide in the reaction mixture.

Known derivatives of haemoglobin which might be formed in the reaction are oxyhaemoglobin $\left(\mathrm{HbO}_{2}\right)$, methaemoglobin (Meth), methaemoglobinhydrogen peroxide (Meth- $\mathrm{H}_{2} \mathrm{O}_{2}$ ) and methaemoglobin-hydrosulphide. The last of these may be 
dismissed because hydrosulphide did not prolong the life of the intermediate spectrum. For the other three and for the intermediate spectrum, the wavelengths of the absorption maxima and the corresponding $\epsilon_{\mathrm{mEq}}$ are given in Table 5 (Lemberg \& Legge, 1949; Dalziel \& O'Brien, 1954a). Neither $\mathrm{HbO}_{2}$ nor Meth accounts satisfactorily for the intermediate spectrum. The Soret band of Meth at pH 8.5 is at a distinctly different wavelength, and moves from $405 \mathrm{~m} \mu\left(\epsilon_{\mathrm{mEq}}=165\right)$ at $\mathrm{pH} 6$ to $413 \mathrm{~m} \mu$ $\left(\epsilon_{\mathrm{mEq} .}=106\right)$ at $\mathrm{pH}$ 10. If the intermediate spectrum is attributed to $\mathrm{HbO}_{2}$, it must also be assumed, to account for the low extinction coefficients, that $40 \%$ of the $\mathrm{Hb}$ is simultaneously converted into products with little specific absorption, and to account for the fact that under some conditions $80 \%$ of the $\mathrm{Hb}$ is eventually recovered (Table 3 ), that one of these products is also reconverted into $\mathrm{Hb}$. Moreover, since the extinction coefficients of the intermediate spectrum are reproducible to within about $5 \%$, the high proportion of these other products formed must be approximately constant over a wide range of reactant concentrations and pH. These conditions are improbable; and a complicated mechanism would be required to explain the persistence and slow deoxygenation of $\mathrm{HbO}_{2}$ in the presence of excess of dithionite.

The intermediate spectrum differs significantly from that of Meth- $\mathrm{H}_{2} \mathrm{O}_{2}$ only in that it shows a maximum at $582 \mathrm{~m} \mu$, consistently higher than that at $545 \mathrm{~m} \mu$. It could be accounted for by the assumption that in the initial rapid reaction with hydrogen peroxide about $90 \%$ of the $\mathrm{Hb}$ is converted into Meth $-\mathrm{H}_{2} \mathrm{O}_{2}$ and the rest into a derivative with little specific absorption in the Soret region and a maximum at about $580-590 \mathrm{~m} \mu, \epsilon_{\mathrm{mEq}} \bumpeq$. 10. The degree of reproducibility of the broad, shallow maximum at $582 \mathrm{~m} \mu$ permits considerable variation of such a small proportion of a secondary product formed under different conditions. A precursor of choleglobin might well exhibit such spectral properties and be formed either simultaneously with Meth $-\mathrm{H}_{2} \mathrm{O}_{2}$ or very rapidly from it, and persist in a stationary state during the life of peroxide. There was some spectrokinetic evidence that the extinction changes near $580 \mathrm{~m} \mu$ were associated with chole-

Table 5. Wavelengths of absorption maxima and milliequivalent extinction coefficients (in parentheses) for some haemoglobin derivatives and the intermediate spectrum at $\mathrm{pH} \mathbf{8 \cdot 5}$

Oxyhaemoglobin

Methaemoglobin

Methaemoglobin-

hydrogen peroxide

Intermediate spectrum
Absorption maxima $(\mathbf{m} \mu)$

$\begin{array}{lll}415(128) & 541(15) & 576(16) \\ 408(120) & 541(8 \cdot 5) & 576(8 \cdot 0) \\ 418(105) & 545(10 \cdot 5) & 582(8 \cdot 6) \\ & & \\ 417(90) & 545(9 \cdot 0) & 582(9 \cdot 6)\end{array}$

globin formation, and in the presence of carbon monoxide a precursor of carboxycholeglobin, $\lambda_{\max } 600 \mathrm{~m} \mu$, was detected.

Meth- $\mathrm{H}_{2} \mathrm{O}_{2}$ has properties consistent with the observed features of the reaction. It has been characterized as an unstable intermediate in the reaction between Meth and $\mathrm{H}_{2} \mathrm{O}_{2}$ at $\mathrm{pH} \mathrm{6-9 \cdot 5}$, which results ultimately in the oxidative degradation of part of the protohaem, and the formation at pH 6 of a green pigment distinct from choleglobin (Keilin \& Hartree, 1951; Dalziel \& O'Brien, $1954 a, b)$. Until recently, it was assumed to be a ferric peroxide complex (Keilin \& Hartree, 1935; Haurowitz, 1935), and if this were so the fact that its formation from methaemoglobin at $\mathrm{pH} 8.5$ is slower than that of the compound from $\mathrm{Hb}$ in the presence of dithionite, with the same peroxide concentration, would be difficult to reconcile with the identity of the two compounds. There is reason to believe, however, by analogy with MetMb- $\mathrm{H}_{2} \mathrm{O}_{2}$ (George \& Irvine, 1952, 1954 ; Theorell \& Ehrenberg, 1952) that Meth- $\mathrm{H}_{2} \mathrm{O}_{2}$ may be a ferryl derivative: its formation from Meth might be represented for example by $\mathrm{Fe}^{3+}$ ion $+\mathrm{H}_{2} \mathrm{O}_{2} \rightarrow \mathrm{FeO}^{2+}$ ion $+\mathrm{OH}+\mathrm{H}^{+}$ ion, and from $\mathrm{Hb}$ by $\mathrm{Fe}^{2+}$ ion $+\mathrm{H}_{2} \mathrm{O}_{2} \rightarrow \mathrm{FeO}^{2+}$ ion $+\mathrm{H}_{2} \mathrm{O}$, and there is no reason why the latter reaction should not be faster than the former. Again, the addition of $\mathrm{Na}_{2} \mathrm{~S}_{2} \mathrm{O}_{4}$ to a solution of Meth and hydrogen peroxide at $\mathrm{pH} 8.5$ is followed by a sequence of spectral changes similar to those observed in the $\mathrm{Hb}-\mathrm{Na}_{2} \mathrm{~S}_{2} \mathrm{O}_{4}$-hydrogen peroxide reaction: there is first a slow reaction associated with a general decline of specific absorption, and the Meth- $\mathrm{H}_{2} \mathrm{O}_{2}$ spectrum is then slowly displaced by a $\mathrm{Hb}$ spectrum with a small choleglobin maximum at $630 \mathrm{~m} \mu$ (Dalziel \& O'Brien, 1954a). Judged by the rate of increase of extinction at $430 \mathrm{~m} \mu$, the rate of $\mathrm{Hb}$ regeneration is slower than in the present experiments, but this difference is of uncertain significance in view of the complexity of the reactions.

The life of the intermediate spectrum is associated with a molar paramagnetic susceptibility value of $4500 \pm 500$ c.g.s.e.m.u. (Dalziel \& Ehrenberg, 1955). Values of this order (3000-5000) are common to MetMb- $\mathrm{H}_{2} \mathrm{O}_{2}$ and -methyl $\mathrm{H}_{2} \mathrm{O}_{2}$ and the peroxide compounds of types II and III of peroxidase and catalase (Theorell \& Ehrenberg, 1952). The susceptibility of Meth- $\mathrm{H}_{2} \mathrm{O}_{2}$ has not yet been measured, but is likely to be of the same order, since it resembles the myoglobin compound quite closely in spectral and other properties. The reaction between MetMb, $\mathrm{Na}_{2} \mathrm{~S}_{2} \mathrm{O}_{4}$ and peroxide at $\mathrm{pH} 8-9$ is accompanied by a sequence of spectral changes similar to those observed with $\mathrm{Hb}$, but differs from the latter in the following respects: (1) the intermediate spectrum in the visible region, $\lambda_{\max } .548 \mathrm{~m} \mu$, $\epsilon_{\mathrm{mM}}=10 \cdot 5, \lambda_{\max } .585 \mathrm{~m} \mu, \epsilon_{\mathrm{mM}}=9 \cdot 0, \cdot$ agreed with 
that reported for $\mathrm{MetMb}-\mathrm{H}_{2} \mathrm{O}_{2}, \lambda_{\max } 549 \mathrm{~m} \mu$, $\epsilon_{\mathrm{mM}}=9.8, \lambda_{\max } .585 \mathrm{~m} \mu, \epsilon_{\mathrm{mM}}=8.4$ (George \& Irvine, 1951); (2) no detectable amounts of cholemyoglobin were formed in the overall reaction; (3) the proportion of the pigment destroyed by haem degradation was smaller than with $\mathrm{Hb}$ under similar conditions; (4) carbon monoxide did not reveal a new intermediate or promote the formation of cholemyoglobin. It is much more likely that myglobin and $\mathrm{Hb}$ differ in the rates or mechanism of haem degradation by hydrogen peroxide in the presence of $\mathrm{Na}_{2} \mathrm{~S}_{2} \mathrm{O}_{4}$ (cf. Dalziel \& O'Brien, 1954b) than that they form different derivatives of intact haem under similar conditions.

Although identification of a transient derivative of $\mathrm{Hb}$ formed in a complex reaction mixture is not easy, and analogy between $\mathrm{Hb}$ and myoglobin must not be over-stressed, the evidence indicates that the intermediate spectrum is due to $\mathrm{Meth}-\mathrm{H}_{2} \mathrm{O}_{2}$ together with a small amount of a substance ultimately converted into choleglobin.

\section{Degradation products}

The main bulk of the $\mathrm{Hb}$ in the reaction mixture escapes destruction as a consequence of the presence of excess of $\mathrm{Na}_{2} \mathrm{~S}_{2} \mathrm{O}_{4}$, and the rest is changed into definable and indefinable products. In alkaline conditions choleglobin is the main recognizable degradation product. But other products with little specific absorption are probably formed, as there is no correlation between the choleglobin formed and the $\mathrm{Hb}$ destroyed, a conclusion supported by the fact that passage of carbon monoxide into the reaction mixture increased carboxycholeglobin formation but not haemoglobin destruction. Oxidative break-up of haem is therefore likely and would explain the decline of absorption intensity over the whole spectrum, including $630 \mathrm{~m} \mu$, during the life of the intermediate compound.

\section{Formation of choleglobin}

The experimental evidence gives but a sketch of the mode of formation of choleglobin. Since $\mathrm{HbCO}$ in $\mathrm{Na}_{2} \mathrm{~S}_{2} \mathrm{O}_{4}$ solutions did not yield the intermediate spectrum with hydrogen peroxide nor undergo degradation, it may be concluded that reaction of hydrogen peroxide at the iron atoms to form Meth $-\mathrm{H}_{2} \mathrm{O}_{2}$ conditions oxidative attack at a methine linkage. From the rate of decline of the Soret maximum of $\mathrm{Meth}-\mathrm{H}_{2} \mathrm{O}_{2}$ during its lifetime the rate of oxidative degradation varies directly with
$\mathrm{Na}_{2} \mathrm{~S}_{2} \mathrm{O}_{4}$ concentration but is independent of hydrogen peroxide concentration. The yield of choleglobin is similarly affected. These facts may be explained by an oxidation-reduction cycle in which Meth- $\mathrm{H}_{2} \mathrm{O}_{2}$ is mainly reduced to $\mathrm{Hb}$ and partly degraded to choleglobin. The choleglobin undergoes further oxidation by hydrogen peroxide and accumulates only when the latter has been largely destroyed.

After the introduction of carbon monoxide into the reacting mixture, during the life of the intermediate spectrum, the presence of a compound closely related to choleglobin was demonstrated. Spectrokinetic measurements were consistent with the following reactions: (a) Meth $-\mathrm{H}_{2} \mathrm{O}_{2} \rightarrow \mathrm{HbCO}$, half-time approx. $2 \frac{1}{2} \mathrm{~min}$.; (b) $\mathrm{X}\left(\lambda_{\max .} 580\right.$ $590 \mathrm{~m} \mu) \rightarrow \mathrm{XCO}\left(\lambda_{\max .} 600 \mathrm{~m} \mu\right)$, complete in $2 \mathrm{~min}$.; (c) $\mathrm{XCO} \rightarrow \mathrm{CO}$-choleglobin, lasting several hours. Reaction $(c)$ is too slow to involve peroxide.

The tentative mechanism in Scheme I relates these reactions. The greatly increased yield of (carboxy)choleglobin brought about by carbon monoxide is attributed to the rapid conversion of $X$ into its carbon monoxide derivative, and the resistance of the latter to further oxidative degradation; it may be that $\mathbf{X}$ and choleglobin, like $\mathrm{Hb}$, only undergo oxidative degradation in a higher oxidation state or as peroxide derivatives. The conversion of XCO into carboxycholeglobin is quantitative. Foulkes, Lemberg \& Purdon (1951) have suggested that cholehaem is derived from pseudohaem, with the grouping $\geqslant \mathrm{C} \cdot \mathrm{CH}(\mathrm{OH}) \cdot \mathrm{C}(\mathrm{OH})\langle$ which could arise by the addition of hydrogen peroxide at a methine linkage of protohaem, and have shown that it is reduced to protohaem by boiling alkali and dithionite. The intermediate XCO rapidly yields cholehaemochromogen with cold alkali and dithionite, and might be an 'oxidized pseudohaem' derivative, with the grouping $>\mathrm{C} \cdot \mathrm{CO} \cdot \mathrm{C}(\mathrm{OH})$ 〈 which Foulkes et al. (1951) believe to be the next stage in the oxidative degradation of $\mathrm{Hb}$.

\section{Sulphaemoglobin}

The introduction of hydrosulphide into a reaction mixture of $\mathrm{Hb}, \mathrm{Na}_{2} \mathrm{~S}_{2} \mathrm{O}_{4}$ and hydrogen peroxide at pH 8.5-9.5 during the life of the intermediate spectrum caused the immediate disappearance of the latter and the formation of large quantities of a green pigment, $\lambda_{\max } 622 \mathrm{~m} \mu$ shifting to $616 \mathrm{~m} \mu$ on treatment with carbon monoxide. These results

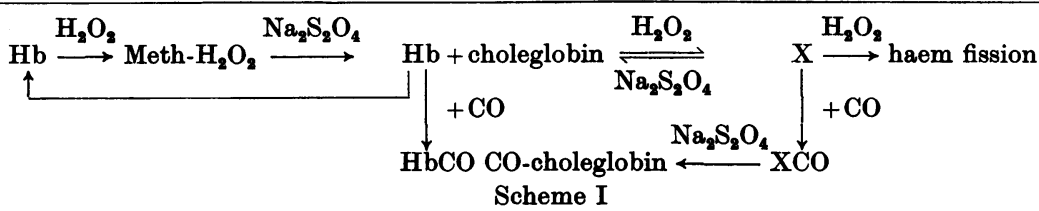


suggest that sulphaemoglobin is formed by the intervention of hydrosulphide at some intermediate stage in the oxidative fission of the methine bridge. Foulkes et al. (1951) suggested a structure for the prosthetic group of sulphaemoglobin closely related to that of cholehaem, with the grouping

$$
\geqslant \mathrm{C} \cdot \mathrm{C}(\mathrm{SH}) \cdot \mathrm{C}(\mathrm{OH})\langle
$$

in place of a methine bridge. Lemberg \& Legge (1949) have postulated the formation of sulphaemoglobin and choleglobin from the same precursor, a peroxide derivative of $\mathrm{Hb}$. The rapidity of the reaction which follows the introduction of hydrosulphide probably accounts for the variations in the sulphaemoglobin yield under apparently identical conditions. Although complete conversion of $\mathrm{Hb}$ into sulphaemoglobin has never been achieved, Drabkin \& Austin (1935-36) estimated $\epsilon_{\mathrm{mEq}}=10-11$ at $620 \mathrm{~m} \mu$ for pure sulphaemoglobin, and Lemberg et al. (1942) give $\epsilon_{\mathrm{mEq} .}=16$ at $617 \mathrm{~m} \mu$ for carbon monoxide-sulphaemoglobin. On the basis of these figures, it would appear that the sulphaemoglobin yield in some of our experiments was close to $100 \%$. This conclusion cannot be accepted, since the spectrum of the product showed a pronounced Soret band, $\lambda_{\max .} 424, \epsilon_{\mathrm{mEq} .}=97$, and according to Lemberg et al. (1942) carbon monoxide-sulphaemoglobin, like choleglobin, has relatively weak absorption in the Soret region. Moreover, with alkali and dithionite the products apparently yielded a mixture of proto- and chole-haemochromogen, although there was no evidence of the presence of choleglobin in the products themselves. There is evidence that sulphaemoglobin yields protohaemochromogen derivatives (Nijveld, 1943; Lemberg et al. 1942).

Choleglobin, sulphaemoglobin and other 'green haemoglobins' such as pseudohaemoglobin (Barkan \& Schales, 1937, 1938) and cruoralbin (Holden, 1943,1945 ), have generally been obtained by the relatively slow oxidation of $\mathrm{Hb}$ or $\mathrm{HbO}_{2}$ under different conditions. The present work shows that two such derivatives can be obtained in quantity in rapid reactions which follow the successive addition of peroxide and a second reagent to $\mathrm{Hb}$ in dithionite solution, provided the second reagent is added during the lifetime of an unstable peroxide derivative of $\mathrm{Hb}$. The results support the general mechanism advanced by Lemberg and his co-workers for these reactions (Lemberg \& Legge, 1949; Foulkes et al. 1951), although they favour the view that the so-called Meth $-\mathrm{H}_{2} \mathrm{O}_{2}$, rather than a ferrous peroxide complex (Lemberg, Legge \& Lockwood, 1938, $1939,1941 a, b)$, is the intermediate involved, and emphasize the importance of the time factor and the use of dilute solutions, in which the life of the peroxide derivative is longest. More detailed studies by means of the compound rapid-flow method of Hartridge \& Roughton (1924), whereby a second reagent, e.g. carbon monoxide, hydrosulphide or cyanide, can be introduced at various intervals after the addition of peroxide may clarify the relationship between the various green haemoglobins. The difference between the reactions of $\mathrm{Hb}$ and myoglobin with peroxide and dithionite, and the relationship between these reactions and products and those of Meth with peroxide, in which a green pigment distinct from choleglobin is formed (Keilin \& Hartree, 1951 ; Dalziel \& O'Brien, 1954b), also deserve further study, and may bear upon the mechanism of peroxidase activity.

\section{SUMMARY}

1. The reaction between haemoglobin, dithionite and hydrogen peroxide has been investigated by spectrokinetic measurements. The results show that by reaction with the peroxide, haemoglobin is largely converted into an unstable derivative, which persists for a definite period, and is then largely reduced to haemoglobin by the excess of dithionite. In the overall reaction, part of the haemoglobin is destroyed, and small amounts of choleglobin are formed at $\mathrm{pH} \mathrm{7-10}$ and of sulphaemoglobin at pH 6.

2. The intermediate compound is probably methaemoglobin-hydrogen peroxide, which exists in a mixture with a small proportion of a substance subsequently converted into choleglobin.

3. A new unstable intermediate has been detected in the reaction at $\mathrm{pH} 8.5-9.5$ in the presence of carbon monoxide, which is characterized by a maximum at $600 \mathrm{~m} \mu$, and is slowly but quantitatively converted into carboxycholeglobin in the presence of excess of dithionite.

4. The addition of hydrosulphide to a reacting mixture of haemoglobin, dithionite and peroxide during the life of the peroxide intermediate at $\mathrm{pH}$ 8.5-9.5 at once gives a large yield of a derivative with the spectroscopic properties of sulphaemoglobin.

5. A mechanism is discussed for these reactions.

6. Experiments indicate that myoglobin is temporarily but completely converted into metmyoglobin-hydrogen peroxide on treatment with hydrogen peroxide in the presence of excess of dithionite. Small amounts of pigment were destroyed in the overall reaction, but there was no evidence of the formation of cholemyoglobin or other green pigments.

7. The explanation previously advanced for the action of oxygen on haemoglobin solutions containing dithionite is confirmed.

We wish to thank Mr B. A. Collett for technical assistance in part of this work. We are indebted to Professor Hugo Theorell for a gift of myoglobin. One of us (K.D.) is indebted to the Nuffield Haematology Fund for financial support. 


\section{REFERENCES}

Barkan, G. \& Schales, O. (1937). Hoppe-Seyl. Z. 248, 96. Barkan, G. \& Schales, O. (1938). Hoppe-Seyl. Z. 253, 83.

Bassett, H. \& Durrant, R. G. (1927). J. chem. Soc. p. 1401. Dalziel, K. (1953). Biochem. J. 55, 79.

Dalziel, K. (1954). Disc. Faraday Soc. 17, 128.

Dalziel, K. \& Ehrenberg, A. (1955). Acta chem. scand. 9, 727.

Dalziel, K. \& O'Brien, J. R. P. (1954a). Biochem. J. 56, 648.

Dalziel, K. \& O'Brien, J. R. P. (1954b). Biochem. J. 56, 660.

Dalziel, K. \& O'Brien, J. R. P. (1957). Biochem. J. 67, 124.

Drabkin, D. L. (1945). Amer. J. med. Sci. 209, 268.

Drabkin, D. L. \& Austin, J. H. (1935-36). J. biol. Chem.112, 51.

Foulkes, E. C., Lemberg, R. \& Purdon, P. (1951). Proc. Roy. Soc. B, 138, 386.

George, P. \& Irvine, D. H. (1951). Nature, Lond., 168, 164.

George, P. \& Irvine, D. H. (1952). Biochem. J. 52, 511.

George, P. \& Irvine, D. H. (1954). Biochem. J. 58, 188.

Hartridge, H. \& Roughton, F. J. W. (1924). Proc. Camb. phil. Soc. 22, 426.

Haurowitz, F. (1935). Hoppe-Seyl. Z. 232, 159.

Holden, H. F. (1943). Aust. J. exp. Biol. med. Sci. 21, 159.

Holden, H. F. (1945). Aust. J. exp. Biol. med. Sci. 23, 255.
Keilin, D. \& Hartree, E. F. (1935). Proc. Roy. Soc. B, 117, 1. Keilin, D. \& Hartree, E. F. (1951). Biochem. J. 49, 88.

Legge, J. W. \& Roughton, F. J. W. (1950). Biochem. J. 47, 43.

Lemberg, R., Holden, H. F., Legge, J. W. \& Lockwood, W. H. (1942). Aust. J. exp. Biol. med. Sci. 20, 161.

Lemberg, R. \& Legge, J. W. (1949). Haematin Compounds and Bile Pigments, 1st ed. New York: Interscience.

Lemberg, R., Legge, J. W. \& Lockwood, W. H. (1938). Nature, Lond., 142, 148.

Lemberg, R., Legge, J. W. \& Lockwood, W. H. (1939). Biochem. J. 33, 754.

Lemberg, R., Legge, J. W. \& Lockwood, W. H. (1941a). Biochem. J. 35, 328.

Lemberg, R., Legge, J. W. \& Lockwood, W. H. (1941b). Biochem. J. 35, 339.

Michel, H. O. (1938). J. biol. Chem. 126, 323.

Nijveld, H. A. W. (1943). Rec. Trav. chim. Pays-Bas, 62, 293.

Theorell, H. \& Ehrenberg, A. (1951). Acta chem. scand. 5, 283.

Theorell, H. \& Ehrenberg, A. (1952). Arch. Biochem. Biophys. 41, 442.

Vogel, A. I. (1939). Quantitative Inorganic Analysis, 1st ed., p. 810. London: Longmans, Green and Co.

\title{
The Fractionation of Urinary Iodine
}

\author{
1. METHOD OF ANALYSIS* \\ BY K. FLETCHER $\dagger$ \\ Medical Research Council Department of Clinical Research, University College Hospital \\ Medical School, London
}

(Received 4 January 1957)

The metabolism of radioactive iodine has been the subject of intensive investigation in recent years. This has been concentrated mainly on the production of hormone by the thyroid gland and its subsequent fate in the plasma and tissues, and little has been published about the excretion of the hormone in the urine. It is, however, generally agreed that the greatest proportion of the iodine in urine is present as inorganic iodide, and only a small percentage exists in an organic form. It was to investigate this organic fraction that the present work was undertaken, both to estimate the amount of organically combined iodine and to discover the chemical nature of the products. This present paper describes a method for the investigation of the problem, and subsequent papers will describe the results obtained from the application of this method

* This work forms part of a Ph.D. Thesis submitted to the University of London.

† Present address: Medical Research Council, Experimental Radiopathology Research Unit, Hammersmith Hospital, London, W. 12. to the urine of patients receiving large amounts of radioactive iodine for the treatment of disease of the thyroid gland.

Several methods were used in an attempt to separate the organic iodine from the iodide, and most were abandoned. The chief cause of the difficulties encountered was the ease with which iodide is oxidized in an acid solution, leading to the formation of free iodine and the production of artifacts. Acland (1952) has pointed out that biological solutions of iodide can readily produce many artifacts when acidified, and this observation has been amply confirmed. The method finally adopted was the removal of iodide from the urine at an alkaline $\mathrm{pH}$ by a column of silver chloride, and the subsequent concentration of the organic iodine by an ion-exchange resin.

\section{EXPERIMENTAL AND RESULTS}

Paper chromatography. Throughout this work chromatography was carried out on Whatman $3 \mathrm{MM}$ paper. This thick paper was chosen since all the material examined contained 